\title{
Effects of probiotic and phytogenic products on performance, gut morphology and cecal microflora of broiler chickens
}

\author{
LIDIJA PERIĆ' ${ }^{1}$ NIKO MILOŠEVIĆ ${ }^{1}$, DRAGAN ŽIKIĆ ${ }^{1}$, SINIŠA BJEDOV ${ }^{1}$, DRAGOLJUB \\ CVETKOVIĆ ${ }^{2}$, SINIŠA MARKOV ${ }^{2}$, MICHAELA MOHNL ${ }^{3}$ and TOBIAS STEINER ${ }^{3}$
}

${ }^{1}$ Faculty of Agriculture, University in Novi Sad, Republic of Serbia, ${ }^{2}$ Faculty of Technology, University in Novi Sad, Republic of Serbia, ${ }^{3} \mathrm{BIOMIN} \mathrm{Holding} \mathrm{GmbH}$, Herzogenburg, Austria

\section{Abstract}

The trial involved 684 Cobb 500 broiler chicks in order to investigate the effects of probiotics and phytogenic additives on performance, gut morphology and cecal microbial concentrations. Birds were assigned to three treatments: control feed, treatment with addition of probiotics in feed and water and treatment with addition of phytogenic blend in feed. The results showed a significant improvement $(P<0.01)$ in body weight gain and a numerical, but non significant $(P>0.05)$ improvement in feed conversion ratio by adding both probiotics and phytogenics in feed. There were no statistically significant differences among treatments regarding total aerobes, anaerobes, lactic acid bacteria, bifidobacteria, enterococci, and Escherichia coli populations $(P>0.05)$ in cecum of broilers. The gut morphology examination showed that probiotics had beneficial effect on jejunum morphology causing a significant $(P<0.005)$ increase in villus height and villus surface area compared to other two groups. On the other hand, phytogenic additive had no effect $(P>0.05)$ on villus height or villus surface area, but reduced the villus/crypt ratio $(P<0.05)$, which may indicate that the improved production results in the group with added phytogenics are not directly connected with changes in gut integrity, but with other physiological mechanisms.

Keywords: broiler, probiotics, phytogenics, intestinal microbiota, gut morphology

\section{Zusammenfassung}

\section{Einfluss Probiotischer und Phytogener Additive auf Leistungsparameter sowie auf Morphologie und Mikroflora des Verdauungstraktes bei Broilern}

Die Wirksamkeit probiotischer und phytogener Futteradditive wurde in einem Fütterungsversuch mit 684 Cobb 500 Broilern untersucht. Die Tiere wurden auf drei Behandlungen verteilt: (1) Kontrollfutter, (2) Applikation von Probiotika im Futter und Tränkwasser, und (3) Applikation eines phytogenen Additivs im Futter. Die Applikation der Additive bewirkte eine Erhöhung der Lebendmasse $(P<0.05)$, sowie eine numerisch reduzierte $(P>0.05)$ Futterverwertung. Die Anzahl an Bakterien (gesamte aerobe und anaerobe Keime, Milchsäurebakterien, Bifidobakterien, Enterokokken, Escherichia coli) im Caecum wies keine Unterschiede $(P>0.05)$ zwischen den Behandlungen auf. 
Die morphologischen Untersuchungen zeigten eine höhere Villuslänge, sowie eine vergrößerte Villusoberfläche im Jejunum am Ende des Versuches bei Applikation der Probiotika. Das Verhältnis der Villushöhe zur Kryptentiefe wurde durch den Einsatz des phytogenen Additivs reduziert $(P<0.05)$. Dies deutet darauf hin, dass die verbesserte Leistung nicht auf einer Veränderung der Darmmorphologie beruht, sondern durch andere Faktoren bedingt ist.

Schlüsselwörter: Broiler, Probiotika, Phytogene Additive, Intestinale Mikroflora, Darmmorphologie

\section{Introduction}

Use of antibiotics as growth promoters is no longer acceptable and therefore it is forbidden in EU countries. Because of that it was necessary to offer other feed additives as an alternative such as enzymes, organic or inorganic acids, plant oils, immunostimulators, microelements, probiotics and prebiotics. Probiotics beneficially affect the host animal by improving its intestinal balance (FULLER 1989). They create gut conditions that suppress harmful microorganisms and favor beneficial ones (LINE et al. 1998, MEAD 2000). They have been largely shown to reduce disease risk, possibly through a reduction in proliferation of pathogenic species, maintaining microbiota balance in the gut (LINE et al. 1998, MACFARLANE and CUMMINGS 1999, MOUNTZOURIS et al. 2007), boost immune function (ZULKIFLI et al. 2000, KABIR et al. 2004) and increase resistance to infection (HERICH et al. 1998, AYSIGl et al. 2005, REKIEL et al. 2007). Beyond the maintenance of health, they have been shown to improve the growth performance of poultry (JIN et al. 1997; Ll et al. 2008) and to have an important influence on gut morphology of broiler chickens (UŠĆEBRKA et al. 2005).

Phytogenic feed additives are plant extracts derived from herbs or spices, which have beneficial effect on animal production and health. A large variety of the plants have properties which could potentially improve feed intake, digestion, feed conversion and body weight gain (LOVKOVA et al. 2001, WILLIAMS and LOSA 2001, ERTAS et al. 2005). The mode of action of these feed additives is not completely clear. They have antimicrobial, antiviral, antioxidant and many other biological activities (ERTAS et al. 2005, CROSS et al. 2007). They act as a digestibility enhancers, stimulating the secretion of endogenous digestive enzymes (WILLIAMS and LOSA 2001, LEE et al. 2003). These traits made phytogenic additives a promising group of growth promoters that are already being used in practice.

The objective of this study was to examine the effects of dietary supplementation of probiotics or phytogenic product in broiler diets compared to standard broiler feed on the growth performance, jejunal morphology and cecal microflora of broiler chicks.

\section{Material and methods}

\section{Animals and diets}

A total of 684 day-old Cobb 500 broilers were assigned to three treatments with six replicates. Each replicate consisted of 38 as-hatched birds per pen. Each floor pen 
measured $2.5 \mathrm{~m}^{2}$, to give a stocking density of $15 \mathrm{birds} / \mathrm{m}^{2}$. Air temperature was adjusted in accordance to the technological demands. Lighting program provided $23 \mathrm{~h}$ of light $+1 \mathrm{~h}$ of dark. Birds were vaccinated against Newcastle disease (NCD) and infectious bursal disease (IBD) as per commercial recommendations.

Feed and water supply were ad libitum. Feed was composed according to the technological demands of the concerned hybrid (Table 1) and it was the same for all groups, except added additives.

Table 1

Composition (\%) of the basal diets

Zusammensetzung (\%) der Basalrationen

\begin{tabular}{lccc}
\hline Ingredient & Starter, 1-21 d & Grower, 22-35 d & Finisher, 36-42 d \\
\hline Corn & 47.50 & 55.24 & 61.70 \\
Soybean meal & 34.24 & 24.85 & 22.48 \\
Full fat soybeans (extruded) & 10.20 & 11.85 & 7.79 \\
Vegetable oil & 4.00 & 4.00 & 4.00 \\
Limestone & 1.30 & 1.18 & 1.09 \\
Monocalcium phosphate & 1.30 & 1.39 & 1.40 \\
Salt & 0.30 & 0.30 & 0.38 \\
DL-methionine & 0.16 & 0.19 & 0.16 \\
Vitamin + mineral premix ${ }^{1}$ & 1.00 & 1.00 & 1.00 \\
Total & 100 & 100 & 100 \\
Nutrients and energy level (calculated) & & & \\
Crude protein, \% & 22.80 & 20.00 & 18.00 \\
ME MJ/kg & 13.00 & 13.40 & 13.40 \\
Lysine, \% & 1.31 & 1.10 & 0.96 \\
Methionine, \% & 0.51 & 0.50 & 0.45 \\
Calcium, \% & 0.90 & 0.85 & 0.80 \\
Total P, \% & 0.70 & 0.70 & 0.67 \\
Available P, \% & 0.44 & 0.44 & 0.41 \\
\hline
\end{tabular}

${ }^{1}$ Vit+mineral mixture provides per kg of diet: $12000 \mathrm{IU}$ of vitamin $\mathrm{A} ; 5000 \mathrm{IU}$ of vitamin D3; $50 \mathrm{mg}$ of vitamin $\mathrm{E} ; 4$ $\mathrm{mg}$ of vitamin $\mathrm{K} 3 ; 4 \mathrm{mg}$ of vitamin B1; $10 \mathrm{mg}$ of vitamin B2; $6 \mathrm{mg}$ of vitamin B6; $60 \mathrm{mg}$ of nicotinamide; $2 \mathrm{mg}$ of folic acid; $0.02 \mathrm{mg}$ of vitamin B12; $0.2 \mathrm{mg}$ of biotin; $400 \mathrm{mg}$ of choline chloride; $15 \mathrm{mg}$ of pantothenic acid; $2 \mathrm{mg}$ of I. $40 \mathrm{mg} \mathrm{Fe}, 100 \mathrm{mg} \mathrm{Zn,} 20 \mathrm{mg} \mathrm{Cu} ; 120 \mathrm{mg} \mathrm{Mn}, 0.3 \mathrm{mg} \mathrm{Se}$

The experimental treatments consisted of control diet (treatment C), the control diet with addition of probiotic blend 1 in drinking water during first three days of life, providing $20 \mathrm{mg} / \mathrm{bird} /$ day and addition of probiotic blend 2 in feed in dose of $1.0 \mathrm{~kg} / \mathrm{t}$ in starter phase, $0.5 \mathrm{~kg} / \mathrm{t}$ in grower phase and $0.25 \mathrm{~kg} / \mathrm{t}$ in finisher phase (treatment PB), and the control diet with addition of phytogenic blend in dose of $125 \mathrm{~g} / \mathrm{t}$ for the whole period (treatment PHY).

The probiotic blend 1 (PoultryStar w, BIOMIN GmbH) comprised probiotic bacteria isolated from the crop (Lactobacillus reuteri), jejunum (Enterococcus faecium), ileum (Bifidobacterium animalis), and cecum (Pediococcus acidilactici and Lactobacillus salivarius) of healthy adult chicken. The product had a total bacterial count, expressed as colonyforming units of $5 \cdot 10^{12} \mathrm{cfu} / \mathrm{kg}$ of product. Probiotic blend 2 (Biomin IMBO, BIOMIN $\mathrm{GmbH}$ ) comprised probiotic bacteria Enterococcus faecium together with prebiotics fructooligosacharides, cell wall fragments and phycophytic substances. Phytogenic blend (Biomin P.E.P. 125 poultry) was composed of essential oils derived from oregano, anis and citrus, and fructooligosacharides. 
Body weight and feed intake were monitored by pen at weekly intervals and mortality was recorded daily. Birds that died were noted and their bodyweight was used to adjust the feed conversion ratio accordingly. European Production Efficiency Factor (EPEF) was calculated according to the following formula:

$$
\mathrm{EPEF}=\frac{\text { bodyweight }(\mathrm{g}) \times \text { survivalrate }(\%)}{\text { feed conversion } \times \text { duration of trial }(\text { days })}
$$

\section{Methodology of bacterial enumeration}

Conventional microbiological techniques using selective agar media were used for analysis. Cecum sample were homogenized in buffered peptone water and serial of decimal dilution were prepared. Selective agar media were used for enumeration of target bacterial groups - total aerobes (Nutrient Agar - Merck), total anaerobes (WilkensChalgren Agar - HiMedia), lactic acid bacteria (MRS agar - HiMedia), Bifidobacterium spp. (Wilkens-Chalgren Agar with recommended supplements - HiMedia), Escherichia coli and total coliform bacteria (Chromocult Coliform Agar - Merck), enterococci (Chromocult Enterococci Agar - Merck) and Clostridium spp. (TSC Agar - HiMedia). Anaerobic milieu in the anaerobic jar for cultivation of obligatory and facultative anaerobes, was achieved using Anaerocult A (Merck). Anaerobiosis is indicated by the colour change of the Anaerotest A (Merck). Results were expressed as $\log _{10}$ colony forming units per gram of cecum digesta $(\log \mathrm{cfu} / \mathrm{g})$.

\section{Methodology of gut morphology measurements}

At the end of the starter period ( 21 days) and the end of the trial ( 42 days), 8 broilers from each group were slaughtered and small intestines were removed. Samples of jejunum were fixed in Bouin solution, and after histological procedure stained with hematoxylin and eosine. Villus height, villus width, crypt depth and thickness of tunica muscularis were determined using the light microscope and software for image analysis. Apparent villus surface area was estimated by trigonometry as described by IJ et al. (2001). A minimum of 15 measurements were made for each parameter per chicken.

\section{Statistical analyses}

Data are presented as means \pm standard deviation. Data were analyzed by ANOVA using general linear models, followed by a LSD post hoc test to separate means, using StatSoft software (STATISTICA 7, 2005). Results were considered significant when $P<0.05$.

\section{Results}

\section{Performance}

Body weight of the birds were controlled every week. The results (Table 2) showed a significant positive effect of probiotic and phytogenic treatments on body weight of broilers. The differences were established at the end of the starter period ( 3 weeks of age) and maintained until the end of the trial ( 6 weeks of age). The best result was achieved in 
PHY group. These results indicate that the phytogenic product under investigation and probiotics have a growth promoting effect on broiler chickens. Probiotic group also showed a positive effect on feed conversion ratio (FCR) compared to the control group, but the differences were not significant $(P>0.05)$. Mortality rates were not significantly affected by treatments $(P>0.05)$. Broilers of PHY group achieved the best EPEF value.

Table 2

Impact of probiotic or phytogenic additives in broiler diets on the zootechnical performance of broilers Einfluss probiotischer und phytogener Additive auf Leistungsparameter bei Broilern

\begin{tabular}{|c|c|c|c|c|c|}
\hline \multirow{2}{*}{ Parameter } & \multicolumn{3}{|c|}{ Treatment } & \multicolumn{2}{|c|}{ Statistics } \\
\hline & Control (C) & Probiotic (PB) & Phytogenic (PHY) & SE & $P$ value \\
\hline \multicolumn{6}{|c|}{ Body weight, g } \\
\hline 3 weeks & $645 \pm 43.7^{\mathrm{A}}$ & $688 \pm 47.2^{\mathrm{B}}$ & $680 \pm 54.8^{B}$ & 2.94 & $<0.001^{* *}$ \\
\hline 6 weeks & $2135 \pm 278^{A}$ & $2184 \pm 241^{B}$ & $2210 \pm 253^{B}$ & 9.94 & $0.008^{* *}$ \\
\hline \multicolumn{6}{|c|}{ Feed conversion ratio (FCR) } \\
\hline 3 weeks & $1.52 \pm 0.07$ & $1.48 \pm 0.02$ & $1.46 \pm 0.02$ & 0.0028 & 0.2925 \\
\hline 6 weeks & $1.91 \pm 0.06$ & $1.89 \pm 0.07$ & $1.87 \pm 0.10$ & 0.0016 & 0.2204 \\
\hline \multicolumn{6}{|c|}{ Mortality rate, $\%$} \\
\hline 3 weeks & 1.74 & 2.61 & 2.17 & & \\
\hline 6 weeks & 3.07 & 3.07 & 4.38 & & \\
\hline \multicolumn{6}{|c|}{ European Production Efficiency Factor (EPEF) } \\
\hline 6 weeks & 258 & 267 & 269 & & \\
\hline
\end{tabular}

\section{Intestinal microflora}

The composition of cecal bacterial population of chicken (total number of aerobes, anaerobes, lactic acid bacteria, bifidobacteria, enterococci, and Escherichia coli) at the end of the experiment is shown in Figure. Number of Clostridium spp. in all samples was lower than $2 \log \mathrm{cfu} / \mathrm{g}$ and the results are not shown in the figure. Number of coliform bacteria in cecum was not significantly different between treatments $(P>0.05)$ and was much lower (for 1-2 log cfu unit per gram) than the number of Escherichia coli in all cecal samples.

There were no statistically significant differences among treatments regarding total aerobes, anaerobes, lactic acid bacteria, bifidobacteria, enterococci, and Escherichia coli populations $(P>0.05)$. Anaerobic bacteria, lactic acid bacteria and bifidobacteria were dominant bacterial species in cecal contents. Domination of Escherichia coli is a main reason of difficulties in enumeration and identification of coliform bacteria in intestinal samples. Notable reduction in Escherichia coli was found in both experimental groups (PB and PHY) compared to control, but the difference was not statistically significant mostly due to the high variation within groups (SD for PB group was 1.06 and for PHY group 1.20 $\log$ CFU/g). 


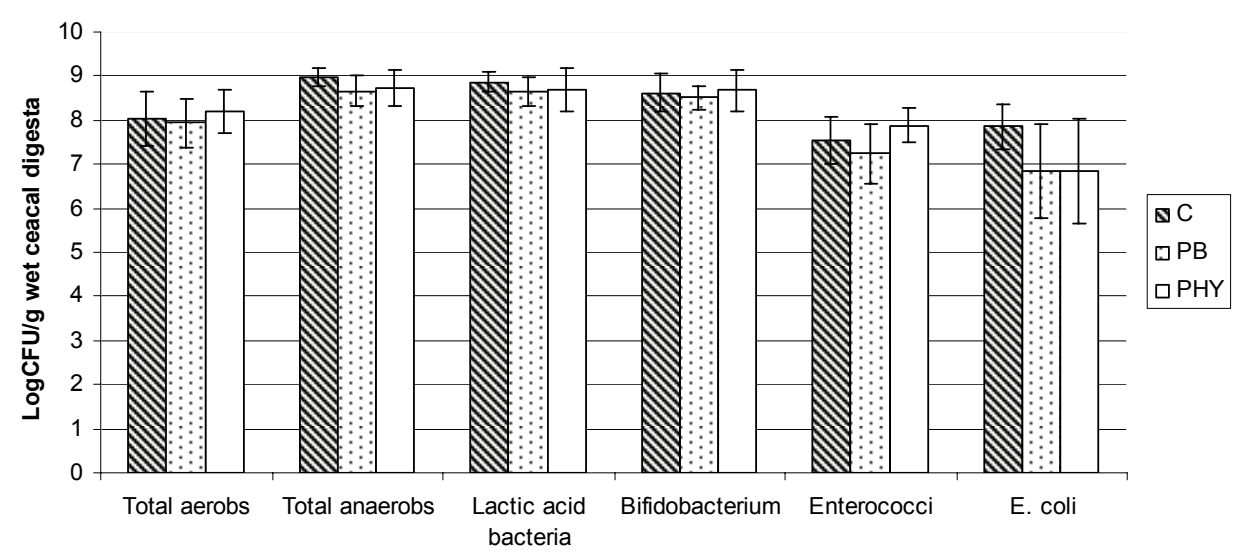

Figure

Number of different bacteria in cecal contents

Anzahl (koloniebildende Einheiten) unterschiedlicher Bakterien im Caecum

\section{Gut morphology}

Significant differences $(P<0.05)$ in examined gut morphology parameters were found between groups at the age of 6 weeks but not at the age of 3 weeks (Table 3 ).

Table 3

Effect of probiotic or phytogenic additives in broiler diets on the jejunum morphology of broilers Einfluss probiotischer und phytogener Additive auf morphologische Parameter des Jejunums bei Broilern

\begin{tabular}{|c|c|c|c|c|c|}
\hline \multirow{2}{*}{ Parameter } & \multicolumn{3}{|c|}{ Treatment } & \multicolumn{2}{|c|}{ Statistics } \\
\hline & Control (C) & Probiotic (PB) & Phytogenic (PHY) & SE & $P$ value \\
\hline \multicolumn{6}{|l|}{3 weeks of age } \\
\hline Villus height, $\mu \mathrm{m}$ & 1181.68 & 1095.10 & 1064.30 & 78.4 & 0.191 \\
\hline Crypth depth, $\mu \mathrm{m}$ & 232.66 & 245.43 & 219.30 & 37.2 & 0.564 \\
\hline Villus/Crypt ratio & 5.08 & 4.46 & 4.85 & 0.96 & 0.753 \\
\hline Surface area, $\mathrm{mm}^{2}$ & 0.105 & 0.124 & 0.119 & 0.01 & 0.838 \\
\hline Villus width, $\mu \mathrm{m}$ & 125.66 & 114.85 & 119.07 & 16.7 & 0.976 \\
\hline Tunica muscularis, $\mu \mathrm{m}$ & 163.48 & 158.33 & 145.67 & 24.8 & 0.653 \\
\hline \multicolumn{6}{|l|}{6 weeks of age } \\
\hline Villus height, $\mu \mathrm{m}$ & $1133.10^{b}$ & $1474.50^{\mathrm{a}}$ & $1249.4^{\mathrm{b}}$ & 85.1 & $0.003^{* *}$ \\
\hline Crypth depth, $\mu \mathrm{m}$ & $245.81^{\mathrm{b}}$ & $281.95^{\mathrm{b}}$ & $334.61^{\mathrm{a}}$ & 52.9 & $0.015^{*}$ \\
\hline Villus/Crypt ratio & $4.69^{b}$ & $5.32^{\mathrm{b}}$ & $3.83^{\mathrm{a}}$ & 0.95 & $0.004^{* *}$ \\
\hline Surface area, $\mathrm{mm}^{2}$ & $0.12^{b}$ & $0.176^{\mathrm{a}}$ & $0.147^{b}$ & 0.04 & $0.001^{* *}$ \\
\hline Villus width, $\mu \mathrm{m}$ & 104.79 & 113.86 & 112.61 & 15.11 & 0.148 \\
\hline Tunica muscularis, $\mu \mathrm{m}$ & 170.52 & 181.48 & 163.92 & 26.31 & 0.846 \\
\hline
\end{tabular}

The results showed that probiotics had a beneficial effect on jejunum morphology at 6 weeks of broilerss age, causing a significant increase $(P<0.005)$ in villus height and villus surface area compared to the other groups, which might be connected with increased production results (Table 2). On the other hand, the phytogenic additive had no effect $(P>0.05)$ on villus height or villus surface area, but reduced $(P<0.005)$ the villus/crypt ratio. That indicates that the improvement in performance parameters achieved in PHY 
group is not directly connected with changes in gut morpfohology, but may be due to other mechanisms.

\section{Discussion}

The beneficial effects of probiotic treatment on broiler performance achieved in this trial are in agreement with a large number of studies which have shown positive effects of using different strains and combinations of probitotics (JIN et al. 1998, ZULKIFLI et al. 2000, KABIR et al. 2004). LI et al. (2008) reported that average daily weight gain was significantly increased and the FCR significantly decreased by application of B. subtilis in feed for broilers, either solely or in combination with other prebiotics. On the other hand there are research stuidies reporting the lack of effect of probiotics on broiler performance (WATKINS and KRATZER 1984, MAIOLINO et al. 1992). In order to give the scientific explanation of the different results achieved by using probiotics as growth promoters in broiler feed, most of the authors concluded that the efficacy of probiotic application depends on many factors including species composition of probiotics, administration levels, application methods, overall diet composition, bird age and environmental factors (JIN et al. 1997, 1998, PATTERSON and BRUKHOLDER 2003).

The similar conclusion can be drawn for the addition of phytogenic additives in broiler feed. Many experiments investigating the effects of herbs, plant extracts and essential oils on broiler performance yielded contradicting results. Some of the authors reported a significant positive effect of phytogenics on broiler performance (LOVKOVA et al. 2001, WILLIAMS and LOSA 2001, ERTAS et al. 2005, CROSS et al. 2007) while in other trials different phytogenic additives and essential oils did not affect body weight gain, feed intake or feed efficiency in broilers (CROSS et al. 2002, DEMIR et al. 2003, OCAK et al. 2008). It has been suggested that the different results of the trials are due to differences in the composition of phytogenic preparations, different methods used to extract the essential oils form the herbs and the level of the application in feed (CROSS et al. 2007).

The probiotic treatment and phytogenic feed additives implemented in this trial did not have a significant effect on the investigated bacterial groups in the gut. As for phytogenic additives, similar observations were obtained by CROSS et al. (2007). The authors reported that dietary inclusion of five culinary herbs or their essential oils had no effect on the intestinal microflora populations. The results regarding probiotics are numerous and quite inconsistent. Using the same combination of probiotic bacteria (probiotic blend 1) as investigated in this trial, which were unlike to this trial applied during the whole experiment via the feed, MOUNTZOURIS et al. (2007) obtained no significant differences between the control and probiotic treatments regarding total anaerobs, total aerobs, coliforms and Bacteroides spp. in cecum of broilers, but found significantly higher concentrations of Bifidobacterium spp., Lactobacillus spp., and grampositive cocci. Numerous reports indicated that addition of probiotics in feed, either solely or in combination with other feed additives like prebiotics, could regulate the intestinal microflora in order to increase the concentration of the beneficial bacteria such as Lactobacillus ssp. and Streptococcus ssp. and inhibit the reproduction of harmful bacteria in the gut (LINE et al. 1998, FRITS et al. 2000, Ll et al. 2008). Other studies using 
different probiotics have shown no significant influence on the gut microbial composition (JIN et al. 1998, Priyakarange et al. 2003). The general suggestion is that molecular approaches identifying bacterial populations and changes in microbial community are needed to enhance our understanding of intestinal microbial ecology, including the influence of probiotics (APAJALAHTI et al. 1998, ZHU et al. 2002).

Regarding the gut morphology traits, the results of this trial showed a positive effect of probiotics on villi height and villi surface compared to the control and PHY groups. Thus, it can be speculated that increased integrity of the gastrointestinal tract associated with a higher surface area of the villi, resulted in improved production results. It is suggested that probiotic cultures could reduce both the damage of enterocytes and the need for cell renewal in the gut. Obtained results confirmed the fact exposed by many researchers that the gastrointestinal tract can adapt and react morphologically to external factors related to dietary changes, i.e. addition of probiotics (HUISMAN et al. 1990, VAN DER KLIS and VAN DER VOORST 1993). These changes were represented by elongated villi and a higher villi/crypt ratio, which indicate a lower rate of enterocyte-cell migration from the crypt to the villus. It was reported that the intestine can change its surface by growing to length, and/or by increasing or decreasing the height of its villi (IJ et al. 2001, UŠĆEBRKA et al. 2005, ŽIKIĆ et al. 2008).

The phytogenic blend used in this trial did not affect villi height, but caused the highest crypt depth and lowest villus/crypt ratio. OCAK et al. (2008) reported that adding dry peppermint or thyme leaves as a growth promoters in broiler feed had no effect on the relative weights of the whole gut, pancreas and addible inner organs. That indicates that the improved production results obtained in broilers fed the phytogenic additive are not directly connected with the improved gut mrphology, but with other mechanisms. It was reported that active principles of herbs, essential oils or plant extracts may act as digestibility enhancers, balancing the gut microbial ecosystem and stimulating the secretion of endogenous digestive enzymes and thus improving growth performance in poultry (LOVKOVA et al. 2001, WILLIAMS and LOSA 2001, CROSS et al. 2007).

Although most of the studies carried out in this field have shown positive effects of probiotics and phytogenic products on broiler performance, further research is needed to establish the optimal application of such additives including their optimal dosage level in the feed in order to obtain maximum effects.

\section{References}

Apajalahti JHA, Sarkilhti LK, Maki BRE, Heikkinen JP, Nurminen PH, Holben WE (1998) Effective recovery of bacterial DNA and percent-guenine-plus-cytosine -based analysis of community structure in the gastrointestinal tract of broiler chickens. Appl Environ Microbiol 64, 4084-8

Ayisigi K, Atasoglu C, Yurtman IY, Mendes M, Pala A (2005) Effect of probiotic supplementation shortly before and after weaning on growth of Turkish Saanen kids. Arch Tierz 48, 601-11

Cross DE, Acamovic T, Deans SG, McDevitt RM (2002) The effects of dietary inclusion of herbs and their volatile oils on the performance of growing chickens. Br Poult Sci 43, S33-S35

Cross DE, McDevitt RM, Hillman K, Acamovic T (2007) The effect of herbs and their associated essential oils on performance, dietary digestibility and gut microflora in chickens from 7 to 28 days of age. $\mathrm{Br}$ Poult Sci 48, 496-506

Demir E, Sarica S, Ozcan MA, Suicmez M (2002) The use of natural feed additives as alternatives for an antibiotic growth promoter in broiler diets. Br Poult Sci 44, S44-S45 
Ertas ON, Güler T, Çiftçi, M, Dalklllç B, Simsek ÜG (2005) The effect of an essential oil mix derived from oregano, clove and anise on broiler performance. Int J Poult Sci, 4, 879-84

Fuller R (1989) Probiotics in man and animals. J Appl Bacteriol 66, 365-78

Herich R, Boimba A, Nemcova R, Gancarcikova S (1998) The influence of application of probiotic on the immune system of 2-3 month old calves. Arch Tierz 41, 565-72

Huisman J, Van der Poel AFB, Mouwen JMVM, Van Weerden EJ (1990) Effects of variable protein content in diets containing Phaseolus vulgaris beans on performance, organ weight and blood variables in piglets, rats and chickens. Br J Nutr 64, 755-64

Iji PA, Saki AA, Tivey DR (2001) Intestinal structure and function of broiler chickens on diet supplemented with a mannan oligosaccharide. J Sci Food Agric 81, 1186-92

Jin LZ, Ho YW, Abdullah N, Jalaludin S (1997) Probiotics in poultry: Mode of action. Worlds Poult Sci J 53, 351-68

Jin LZ, Ho YW, Abdullah N, Jalaludin S (1998) Growth performance, intestinal microbial populations and serum cholesterol of broilers fed diets containing Lactobacillus cultures. Poult Sci 77, 1259-65

Kabir SML, Rahman M M, Rahman MB, Rahman MM, Ahmed SU (2004) The dynamics of probiotics on growth performance and immune response in broilers. Int J Poult Sci 3, 361-4

Lee KW, Everts H, Kappert HJ, Frehner M, Losa R, Beynen AC (2003) Effects of dietary essential oil components on growth performance, digestive enzymes and lipid metabolism in female broiler chickens. Br Poult Sci 44, 450-7

Li X, Qiang L, Liu, Xu CH (2008) Effects of supplementation of fructooligosaccharide and/or Bacillus Subtilis to diets on performance and on intestinal microflora in broilers. Arch Tierz 51, 64-70

Line E J, Bailey S J, Cox NA, Stern N J, Tompkins T (1998) Effect of yeast-supplemented feed on Salmonella and Campylobacter populations in broilers. Poult Sci 77, 405-10

Lovkova MY, Buzuk GN, Sokolova SM, Kliment'eva I (2001) Chemical features of medicinal plants (Review). Appl Biochem Microbiol 37, 229-237

Macfarlane GT, Cummings JH (1999) Probiotics and prebiotics: can regulating the activities of intestinal bacteria benefit health? Br Med J 318, 999-1003

Maiolino R, Fioretti A, Menna LF, Meo C (1992) Research of the efficiency of probiotics in diets for broiler chickens. Nutr Abstr and Rew Series B 62, 482

Mead GC (2000) Prospects for »competitive exclusion« treatment to control salmonellas and other foodborne pathogens in poultry. Vet $J 159,111-23$

Mountzouris KC, Tsirtsikos P, Kalamara E, Nitsch S, Schatzmayr G, Fegeros K (2007) Evaluation of the Efficacy of a Probiotic Containing Lactobacillus, Bifidobacterium, Enterococcus, and Pediococcus Strains in Promoting Broiler Performance and Modulating Cecal Microflora Composition and Metabolic Activities. Poult Sci 86, 309-17

Ocak N, Erener G, Burak AKF, Sungu M, Altop A, Ozmen A (2008) Performance of broilers fed diets supplemented with dry peppermint (Mentha piperita L.) or thyme (Thymus vulgaris L.) leaves as growth promoter source. Czech J Anim Sci 53, 169-75

Patterson JA, Burkholder MK (2003) Application of prebiotics and probiotics in poultry production. Poult Sci 82, 627-31

Priyankarage N, Silva SSP, Gunaratne SP, Kothalawala H, Palliyaguru MWCD, Gunawardana GA (2003) Efficacy of probiotics and their effects on performance, carcass characteristics, intestinal microflora and Salmonella incidence in broilers. Br Poult Sci 44, S26-S27

Rekiel A, Wiecek J, Bielecki W, Gajewska J, Cichowicz M, Kulisiewicz J, Batorska M, Roszkowski T, Beyga K (2007) Effect of addition of feed antibiotic flavomycin, or prebiotic BIO-MOS on production results of fatteners, blood biochemical parmeters, morphometric indices of intestine and composition of microflora. Arch Tierz 50 Special Issue, 172-80

StatSoft (2005) Statistika 7. Stat Soft Inc., Tulsa, OK, USA

Ušćebrka G, Žikić D, Perić L, Jurcoane S, Milošević N (2005) Effect of probiotic supplementation on the small intestinum morphology of broiler chickens. Proceedings of The 34th international session of scientific communications of the faculty of animal science, Bucharest, Romania, 67-71

Van der Klis JD, Van der Voorst A.(1993) The effect of carboxymethylcellulose (a soluble polysaccharide) on the rate of marker excretion from the gastrointestinal tract of broilers. Poult Sci 72, 503-12

Watkins BA, Kratzer EH (1984) Drinking water treatment with commercial preparation of a concentrated Lactobacillus culture for broiler chickens. Poult Sci 62, 1671-3

Williams $P$, Losa R (2001) The use of essential oils and their compounds in poultry nutrition. World's Poult 17, 14-5 
Zhu SY, Zhong T, Pandya Y, Joerger RD (2002) 16S rRNA-based analysis of microbiota fromm the cecum of broiler chickens. Appl Environ Microbiol 68, 124-37

Zulkifli I, Abdullah N, Azrin NM, Ho YW (2000) Growth performance and immune response of two commercial broiler strains fed diets containing Lactobacillus cultures and oxytetracycline under heat stress conditions. Br Poult Sci 41, 593-7

Žikić D, Perić L, Ušćebrka G, Stojanović S, Milić D, Nollet L (2008) Effect of prebiotics in broiler breeder and broiler diets on performance and jejunum morphology of broiler chickens. 1st Mediterranean Summit of WPSA, Book of Proceedings, Porto Carras, Greece, 879-82

Received 13 February 2009, accepted 17 December 2009.

Corresponding author:

LIDIJA PERIĆ

email: lidija@polj.uns.ac.rs

Department of Animal Science, Faculty of Agriculture, Trg Dositeja Obradovića 8, 21000 Novi Sad, Republic of Serbia 